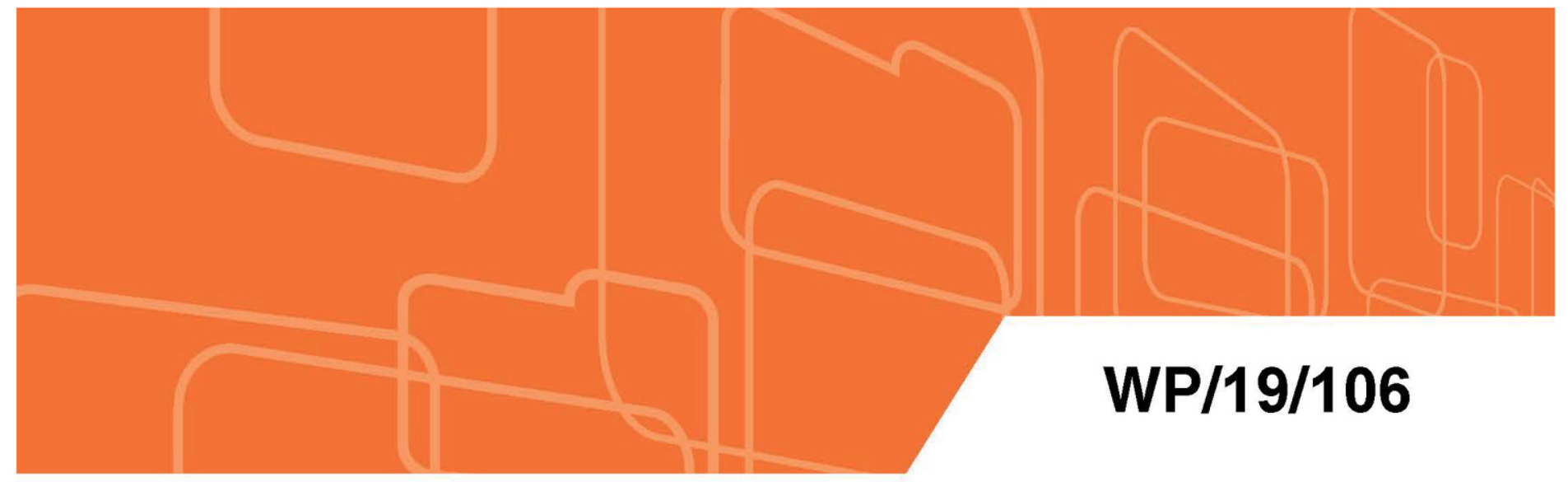

IMF Working Paper

\title{
Pledged Collateral Market's Role in Transmission to Short-Term Market Rates
}

\author{
by Manmohan Singh and Rohit Goel
}

IMF Working Papers describe research in progress by the author(s) and are published to elicit comments and to encourage debate. The views expressed in IMF Working Papers are those of the author(s) and do not necessarily represent the views of the IMF, its Executive Board, or IMF management. 


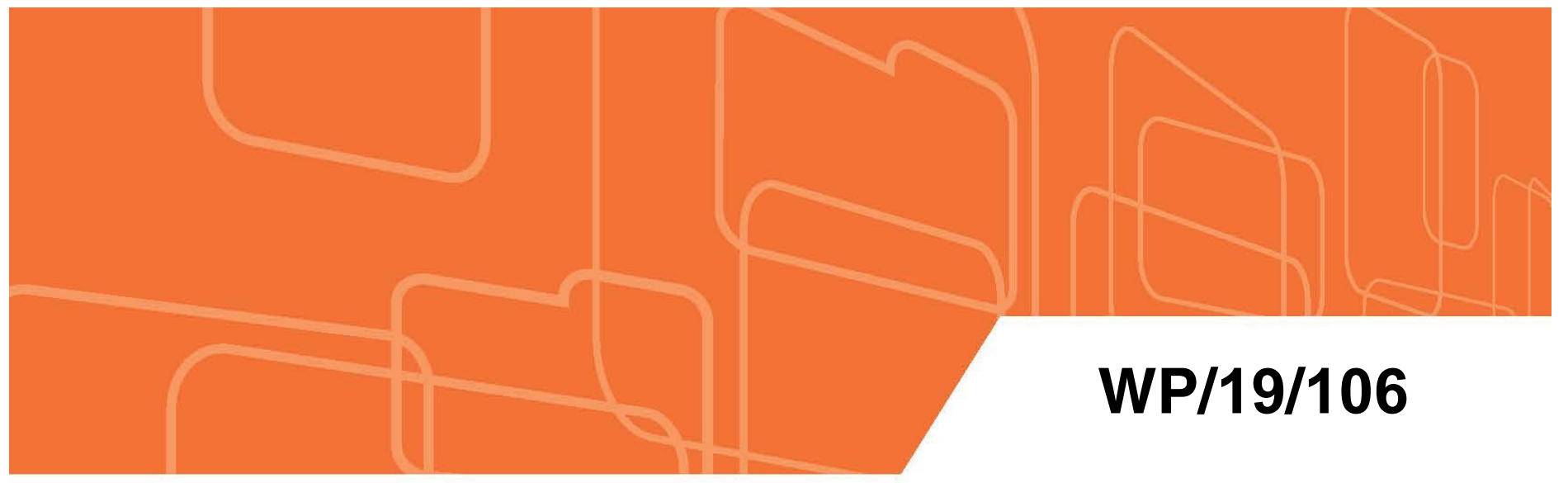

\title{
Pledged Collateral Market's Role in Transmission to Short-Term Market Rates
}

\author{
by Manmohan Singh and Rohit Goel
}

IMF Working Papers describe research in progress by the author(s) and are published to elicit comments and to encourage debate. The views expressed in IMF Working Papers are those of the author(s) and do not necessarily represent the views of the IMF, its Executive Board, or IMF management. 


\title{
IMF Working Paper
}

Monetary and Capital Markets Department

\section{Pledged Collateral Market's Role in Transmission to Short-Term Market Rates}

\author{
Prepared by Manmohan Singh and Rohit Goel ${ }^{1}$ \\ Authorized for distribution by Gaston Gelos
}

May 2019

\begin{abstract}
IMF Working Papers describe research in progress by the author(s) and are published to elicit comments and to encourage debate. The views expressed in IMF Working Papers are those of the author(s) and do not necessarily represent the views of the IMF, its Executive Board, or IMF management.
\end{abstract}

\begin{abstract}
In global financial centers, short-term market rates are effectively determined in the pledged collateral market, where banks and other financial institutions exchange collateral (such as bonds and equities) for money. Furthermore, the use of long-dated securities as collateral for short tenors - or example, in securities-lending and repo markets, and prime brokerage funding - impacts the risk premia (or moneyness) along the yield curve. In this paper, we deploy a methodology to show that transactions using long dated collateral also affect shortterm market rates. Our results suggest that the unwind of central bank balance sheets will likely strengthen the monetary policy transmission, as dealer balance-sheet space is now relatively less constrained, with a rebound in collateral reuse.

JEL Classification Numbers: G21; G28; F33;K22;G18;G15
\end{abstract}

Keywords: central banks balance sheet, monetary policy transmission,collateral velocity

Authors’ E-Mail Addresses: msingh@imf.org, rgoel@imf.org

\footnotetext{
${ }^{1}$ With special thanks to comments and feedback from Gaston Gelos, Luis Brandao-Marques, Roland Meeks, James Aitken, Ulrich Bindseil, Andrew Filardo, George Selgin, Phil Prince, Matt King, Benson Durham, Darrell Duffie, Patrizia Bussoli, and various market participants who wish to remain anonymous. Remaining errors are our own.
} 


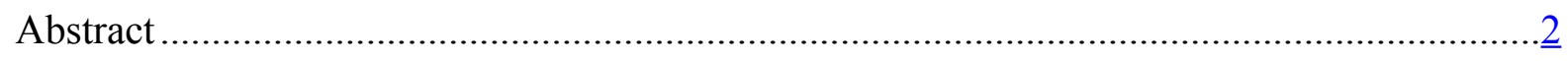

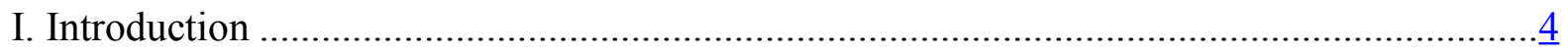

II. Moneyness and Risk Premia .................................................................................. 5

III. Lean Central Bank Balance Sheets and Monetary Transmission-Some Analytics...........

IV. Dealer Balance Sheet Space and Financial Conditions ...........................................12

V. Collateral Reuse Rebounds_implications for Money Market Rates .............................13

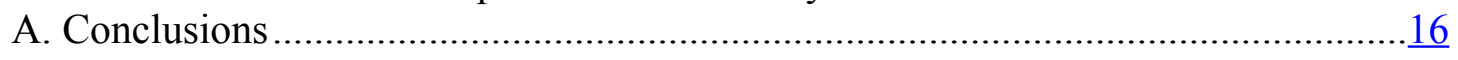

References...............................................................

Tables

1. Coefficients and Significance Level of the Collateral Variable (in risk

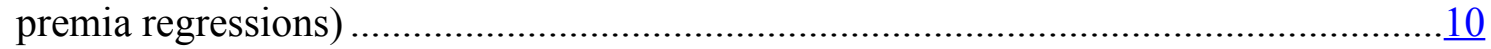

2. Sources of Pledged Collateral, Volume of Market, and Velocity ....................................15

Figures

1. Coefficients for the Collateral Variable Across Different Tenors of Risk Premia ..............10

2. Market Plumbing ............................................................................................ 11

3. Pledged Collateral Received by U.S. Banks and European Banks .................................14

Boxes

1. Global Banks Footprint in Financial Plumbing —A Primer .......................................... $\underline{8}$

2. Analytics on Reverse Regressions - Transmission to Short End ....................................10

Annex

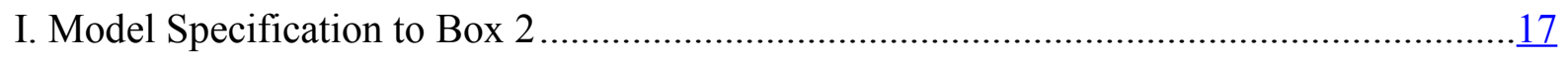




\section{INTRODUCTION}

Most regression-based models used to estimate term premia start from the assumption that policy rates affect the long end. Del Negro et al for instance, tracked changes in the term premium over time and decomposed that premium into a "safety" premium and a "liquidity" premium. Historically, most of the research tries to explain the term premia using the expected path of the future short-term rates. This is in line with the standard monetary policy transmission mechanism whereby central banks generally target a short-term rate. These short-term rates, combined with investor's preferences at different maturities of the yield curve (also called as the preferred habitat hypothesis) and fundamental economic factors, "pass-through" to the long-term rates. This transmission channel has been researched extensively in the literature.

However, there is a need to show that changes in long-tenor securities also affect short-term rates. This happens for instance via the slicing-dicing of long tenor bonds for repo/prime brokerage/securities-lending, etc., that rolls down to the short end. Through this transmission channel, the supply-demand dynamics at the long-end can feed back into the short-end rates. This is even more relevant in the post global financial crisis (GFC) era, when the collateral market has declined sharply and the expected short-term rates were bolted near zero by quantitative easing (Christensen and Rudebusch, 2012). As background, in the aftermath of quantitative easing (QE) or a variant thereof, expanded central bank balance sheets that silo sizeable holdings of United States (U.S.) treasuries, United Kingdom (U.K.) gilts, Japanese government bonds (JGBs), German bunds and other AAA (or somewhat lower) eurozone collateral, have placed central bankers in the midst of market plumbing that determines the short-term rates. Given their sizable footprint in the market for such collateral, it will be very difficult for them to walk away from that role. Thus, this channel and the potential implications for the monetary policy transmission are critical to examine.

Some recent attempts to show the impact of collateral reuse from long tenor bonds include Arrata et al (2018), and Jank and Moench (forthcoming, 2019). Both papers use data on asset purchases and securities lending by eurozone central banks to see the impact on repo market rates and collateral reuse in the eurozone. However, the market for good collateral (for example, bunds or U.S. treasuries) is also impacted by hedge funds, derivative margin flows, and securities-lending and repo done outside the eurozone. Thus, our focus is on the global financial centers that determine the (short-term) rates in the pledged collateral market, where banks and other financial institutions exchange collateral (such as bonds and equities) for money.

This paper contributes to a better understanding of the term structure of interest rates and risk premia. Term premia traditionally represents the compensation that risk-averse investors demand for holding long-term bonds (Adrian et al 2013). However, there are a number of other influences that may affect premia for longer tenors (Cohen 2018), including for instance the official sector purchases of government bonds that can result in supply-demand imbalances. Such effects may be compounded by demand for long-term bonds from insurance and pension funds, as they try to hedge duration risk, especially in an environment of falling yields (Domanski et al, 2015). Apart from these and other macroeconomic factors (Hordahl and Tristani, 2014), the role of collateral in shaping risk premia is increasingly 
relevant in the aftermath of QE. While some models suggest that the scarcity of collateralizable wealth leads to a term premium (Williamson, 2014), there is limited empirical research on how the global collateral markets impact the transmission from the long-dated securities to the short-end market rates through the risk premia channel.

We seek to fill this gap through our research and demonstrate that the unwind of central bank balance sheets will likely strengthen the monetary policy transmission. The economic explanation (and theory thereof) of unwinding central bank balance sheets remains relatively obscure. Several central bank speeches (especially from the Fed), since early 2017 have suggested that central bank unwind is similar to rate hikes (and leads to tightening). However, Brainard (2017) in the context of cross-border spillovers admits that there will be important implications if policy rate hikes and balance sheet reductions are not equivalent. Singh and Wang (2017) show that interest rate hikes and balance sheet unwind are not equal; in fact, the former leads to an unambiguous tightening, while the latter may lead to a loosening of financial conditions if the dealer balance sheet space is not constrained.

In this paper, we deploy a framework adapted from the Global Financial Stability Report (GFSR) October 2018 (Annex I) to understand the transmission from the long-dated securities to the short-term market rates. Using this methodology, we focus on what the unwinding of central bank balance sheets and forthcoming regulatory tweaks might entail for money market rates. We show that the unwind of such good collateral from central bank balance sheets to the market is likely to improve transmission from the long tenor bonds to the short-end money market rates. This finding is especially relevant as global central banks, especially in the major advanced economies, are at a critical transitional juncture of their monetary policy.

The rest of the paper is structured as follows. Section II introduces the concept of "moneyness" and how it links to risk premia. Section III analytically uses data from the global pledged collateral market to show that transmission post-Lehman crisis from the longend rates to the short-end rates is weaker than pre-Lehman. In Section IV, we show the interaction of dealer balance sheet space and the central bank balance sheets. Financial plumbing, where money and collateral interface, is a role that has historically always been associated with private-sector balance sheets (that is, bank, nonbanks, custodians, etc.) and not with central bank balance sheets, whose mandate is about monetary policy. Section $\mathrm{V}$ suggests that dealer balance sheet space is relatively less constrained, collateral reuse is rebounding for the first time since the Lehman crisis, and makes a case for the central banks not to compete (and influence price discovery) with market rates. Section VI concludes with a slant towards unwinding good collateral from central bank balance sheets to improve the transmission to the short-end market rates.

\section{Moneyness ANd Risk Premia}

As discussed in the Introduction, regression models used in the literature are asymmetric because they ignore the possibility that changes in supply and demand for long bonds could 
also affect the short-term market rates, and in turn, the management of the policy rate. ${ }^{2}$ There are premia for holding tenor that reflects the services - collateral, alternatives to deposits, regulatory need for HQLA, duration, etc. - that long-term bonds provide to pension, insurers, sovereign wealth funds, hedge funds and the banking system, in addition to any required compensation for uncertainty about the future level of short rates.

The utility value of securities as collateral - the ease with which this instrument can be used to provide credit support for some (continuing) exposure-itself has several features. These include (1) acceptability to counterparties worldwide; (2) ease of use- how likely it is to suddenly become special, how stable is supply; and (3) stability of price (i.e., expected frequency of posting and recalling margin).

Everyone will accept short term treasury bills (t-bills) for everything, but not everyone will accept long bonds - so t-bills will be preferred to bonds on the basis (metric 1). A collateral possessor will have to replace a one-week t-bill every week, and replacing a maturing security entails a larger and more costly operation than a holding non-maturing security-so somewhat longer-term securities possess more collateral value (metric 2). Long bonds have a much higher price volatility, so their value as collateral is diminished (metric 3). Thus, a bill or short coupon with six months to two years to maturity occupy a "sweet" spot, where collateral is easily traded; it provides the highest collateral utility value - intuitively there is a "kink" at the sweet spot; see figure in Box 2 and Singh and Prince (2018).

At the long end, where collateral utility value is eroded by price volatility, the value of duration-matching services for pension and life insurance investors tends to overwhelm the value of collateral services in setting term premia. For instance, the demand for long principal strips with a 3 percent yield seems to be a cap on long U.S. Treasury rates, as demonstrated by the recent tussle at the 3 percent rate for the 10 -year U.S. treasury bond. In the euro area, the Bund general collateral overnight rate is about negative $50 \mathrm{bps} .{ }^{3}$ These rates would probably be much more negative if not for recent securities lending activity by the European Central Bank. This has helped contain negative yields by effectively replacing longer-term bonds bought via QE, with similar collateral and "moneyness" services to the market. At the very shortest end (for example, 3 months), the value of the securities to nonbank institutions as a direct alternative to holding bank deposits (that is, the "moneyness") generally overwhelms the reuse value of collateral. ${ }^{4}$

\footnotetext{
2 The recent tweaks in Interest on Excess Reserves (IOER) by ( 5 bps each in June 2018, December 2018, and May 19) the Fed is an example.

${ }^{3}$ General collateral (or GC rate) is the rate for which specific securities are not identified until after the trade. If there is demand for a specific (i.e., special) security, the rate will be different (i.e., typically lower rate-since collateral rates are lower when demand is higher and vice-versa).

4 Typically, if U.S. treasuries (10 year) are over 3 percent, duration risk is relatively high and overwhelms reuse benefits from the collateral. Thus, if yield curve steepens and 10-year U.S. treasuries are higher (say more than 4 percent), then HQLA demand may shift towards central bank reserves and away from U.S. treasuries. Markets/asset managers should make their preferred moneyness choice between U.S. treasuries and deposits.
} 
So, short-intermediate collateral, generally speaking, contributes most to collateral reuse and the overall liquidity of the financial system. We mention "moneyness" in relation to short securities, but it is important to note that this characteristic exists on a spectrum. It is not binary. There are degrees of "moneyness" depending on how closely the security can substitute for bank deposits, or the ease with which the security can be converted into something else that is a good substitute for bank deposits. Since the demand for debt management and ancillary services is somewhat predictable, the issuance can be optimized to exploit that demand within the risk requirements of debt management. Debt management agencies, especially in advanced economies, should consider the value of collateral services - "moneyness" - and duration services when planning their issuance in addition to more conventional criteria.

\section{Lean Central Bank Balance Sheets and Monetary Transmission—Some ANALYTICS}

For some economists who study central bank balance sheets, there is no clear reason for large reserves being required if monetary policy is actually normalizing. Stella (2015) has argued that banking systems in advanced economies, in normal times, have functioned well despite minimal reserves - well below US $\$ 50$ billion, in the case of the U.S. before the GFC. For a long time, that was a sufficient amount to iron out any deviations in short-term rates, and to keep the effective fed funds rate aligned with overnight market rates, before Lehman Brothers failed. The ensuing financial crisis illuminated the importance of bank liquidity and led to regulatory requirements for HQLA.

Furthermore, the holdings of HQLA across global banks vary, with some biased towards collateral, and others biased towards reserves (Ihrig.,et al., 2017) - this depends on many factors including some who make a market in reserves (Kaminska, 2015), and others (Citi and Morgan Stanley) who prefer collateral (and its reuse potential) to reserves. ${ }^{5}$ However, it is important to note that while bank reserves count as HQLA, securities like treasuries or German bunds count as well (Quarles, 2018). Any differences are only minor: the "moneyness" in collateral offers benefits that make up for the regulatory preference for cash expressed under the net stable funding ratio requirements, which charges 5 percent for government securities compared to 0 percent for cash. Furthermore, when the amount of reserves declines, balance-sheet space with private-sector banks increases; this has its own dynamics via market plumbing and may not result in tightening (Singh, 2017b). Recent arguments (Copeland, et al, 2019) with reference to intra-day payments are not compelling either since the timing of intra-day clearing does not tell us much about the true resource costs of smaller central bank balance sheets. That is, the timing of intra-day payments is too

Central bank reserves are akin to the latter but at attractive rates relative to deposits. Hence, there is a desire by market treasurers not to reduce reserves. If the marginal price for duration is a levered price, then it could conceivably be more sensitive to collateral services than duration.

${ }^{5}$ There is no study like Ihrig et al's (2017) for the European banks, yet. 
sensitive to small pricing differentials to draw strong conclusions, especially when the prices are so distorted by the central banks.

\section{Box 1. Global Banks Footprint in Financial Plumbing-A Primer}

The financial system that includes banks, hedge funds, pension funds, insurers, sovereign wealth funds (SWFs), etc. be represented by entities A to Z. Only a small number (say XYZ) have the capabilities to regularly move financial collateral across borders on a large scale. XYZ also happen to be the large 10-15 banks. Major dealers active in the collateral industry include Goldman Sachs, Morgan Stanley, JPMorgan, Bank of America/Merrill, and Citibank in the U.S. In Europe and elsewhere, important collateral dealers are Deutsche Bank, UBS, Barclays, Credit Suisse, Société Générale, BNP Paribas, HSBC, Royal Bank of Scotland (with a declining share), and Nomura. Recently Canadian banks have also entered this market.

The remaining financial entities, from $A$ to $Z$, that demand and supply collateral need to connect with each other via XYZ. Entry into this market is not prohibited but is extremely expensive and difficult, as it requires having a global footprint and global clients (and the acumen and sophistication to move and price liquid securities very quickly - in seconds sometimes). Note that the triparty collateral agreements restrict the collateral flows only within the triparty structure, as in the U.S, and is thus not a part of this Box

For example, a Chilean pension fund may want Indonesian bonds for six months, and W (for example, a hedge fund, or a securities lender in Hong Kong) may be holding these bonds and is willing to rent out to A for six months for a small fee. But W does not know there is demand from A. Only via XYZ can A connect to W. Since XYZ sits in the middle of the web, they have the ability to optimize in ways that give them an advantage. The Indonesian bonds may come into their possession because XYZ loaned $\mathrm{W}$ money, or because XYZ have a derivative with $\mathrm{W}$, or through a security lending agreement.

Such securities that need to move cross-borders under a "repo," or "security lending," or related transaction need to be legally perfected (and herein legal perfection entails rules such as title transfer and rehypothecation). Similarly, for over-the-counter (OTC) derivative margins, there is an International Swaps and Derivatives Association Master Agreement. For prime-brokerage/HF collateral, there is a similar master agreement that resonates easily between XYZ. Thus, it is not easy for all real economy collateral (e.g., immovable assets, such as buildings) to be able to move across borders. This market for bilateral pledged collateral is the only true market that prices at mark-to-market all HQLA securities (bonds and equities).

Changes in the demand and supply of collateral have been shaped in the post-Lehman era by regulation and central bank asset purchases as follows.

(a) As regulatory 'tweaks' (such as leverage ratio) are implemented, they will soften the balance sheet constraints for XYZ for collateral reuse. Hence, the effective supply of collateral will increase.

(b) Similarly, central banks could provide balance sheet "space" to augment the balance sheets of XYZ; for example, the Fed's reverse repo program since September 2013; or European Central Bank's expanded its collateral framework during the eurozone crisis, or their security-lending program since January 2017. 
The pledged collateral market's transmission to the short-end market rate contributes to the moneyness along the yield curve. Although policy rates do percolate to the long end (at least in theory), we show that the transmission from the pledged collateral market to the short-end market rates is also very relevant. Box 2 shows that the transmission to the short end is weaker post-Lehman era (2008-17) than in the pre-Lehman era (2002-07). The pledged collateral market was about US\$10 trillion pre-Lehman with significant slicing/dicing of longer dated securities into short-tenor instruments (repo, securities-lending, etc.). Immediately post-Lehman, this market collapsed to about half its peak, and remained unchanged until 2016 (initially due to crisis-related haircuts and counterparty risk in dealers; and then QE and regulations). During this period, transmission to short-end rates remained subdued. There is similar research in other areas (e.g., housing) that shows that monetary transmission has not been adversely impacted by household indebtedness (Gelos et al, 2019).

To further enhance our understanding of lean vs. large central bank balance sheets, it is useful to lay out some of the key line items on the liability side of a central bank's balance sheet. The main liability was always currency-in-circulation. This figure (for example, for the Fed) is around US\$1.6 trillion and is likely to reach around US\$2 trillion when the Fed balance sheet is normalized in the medium term. After QE, another line item that is now significant is excess reserves which, along with the two overnight reverse repo programs (RRPs), ${ }^{6}$ disintermediate market functioning. For example, RRPs allow money to be drained from the system, but no collateral is released to the market. This is more of an accounting effect than true reserve drainage, since only line items reshuffle (from excess reserves to RRP) on the liability side of the Fed's balance sheet (Potter, 2015, footnote 2) ${ }^{7}$. This rusts the plumbing since money that could be priced by the market skirts the plumbing as it has direct access to the Fed (see Figure 2).

\footnotetext{
${ }^{6}$ These programs cover foreign official international accounts and nonbanks.

${ }^{7}$ The triparty/DTCC framework that underpins the RRPs, does not release collateral to the market domain. So, money comes to the Fed but collateral is not released to the market for reuse and related plumbing activities. It stays within the triparty system (and counts as HQLA for the owner). Fed's liability side of balance sheet does not change-it is an accounting drainage, and not reserve drainage as decreased reserves take a new name: RRP.
} 


\section{Box 2. Analytics on Reverse Regressions-Transmission to Short End}

Historically, most of the research trying to explain the term structure of interest rates uses the expected path of the future short-term rates. However, there is a need to show reverse regression causality too (for example, via the moneyness in slicing-dicing of long tenor bonds for repo/prime brokerage/sec-lending etc. that rolls down to short end). To determine what affects risk premia (a broader lens than term premia), researchers commonly estimate the econometric relationship between these estimates and observable macroeconomic and financial "factors." We adapt a methodology from a similar model as used in GFSR April 2018, Box 1.2, to understand the role of collateral, and the long-end variables in driving the short-end of the curve. We use the risk premia variable (actual yield minus OIS forwards) at 3,6,12, and 24 months, as our dependent variable in the regressions (for further details, please see Annex I).

Our independent variables are

a) Size of the Global Pledged Collateral Market

b) Determinants of Risk Premia

$$
\text { Risk Premia }=\alpha+\beta * \text { Global Collateral }+\sum \gamma * \text { Proxy }
$$

We run the analysis for the full sample (2002-17) and the regressions indicate that collateral's predictive power is significant across the short as well as medium term horizons. However, since multiple tests show a structural break in late 2007, we focus on pre-Lehman and post-Lehman periods below. The table below summarizes that the coefficient of collateral is lower post-Lehman relative to pre-Lehman, as QE and regulation silo much of the good collateral.

Table 1. Coefficients and Significance Level of the Collateral Variable (in risk premia regressions)

\begin{tabular}{llccc}
\hline & & Overall & \multicolumn{2}{c}{ Collateral } \\
Risk Premia & Duration & Ave. R^2 & $\begin{array}{c}\text { Weighted- } \\
\text { Ave. Beta }\end{array}$ & Ave. P val. \\
\hline \hline 6m Risk Premia & $2002-07$ & $40 \%$ & 0.23524 & 0.0053439 \\
6m Risk Premia & $2008-17$ & $54 \%$ & -0.015143 & 0.40027 \\
& & & & \\
12m Risk Premia & $2002-07$ & $57 \%$ & 0.17113 & 0.067458 \\
12m Risk Premia & $2008-17$ & $54 \%$ & 0.053382 & 0.083095
\end{tabular}

The chart below shows the robustness of Beta(s) over the term structure. The kink in the 6-12 month horizon, is also in line with our priors and highlights the moneyness concept of the pledged collateral market (Section II). Securities with 6-12-month outstanding tenor are in the "sweet spot" for providing the highest collateral value (i.e., time interval for at least one reuse, plus minimal duration risk).

Figure 1. Coefficients for the Collateral Variable Across Different Tenors of Risk Premia

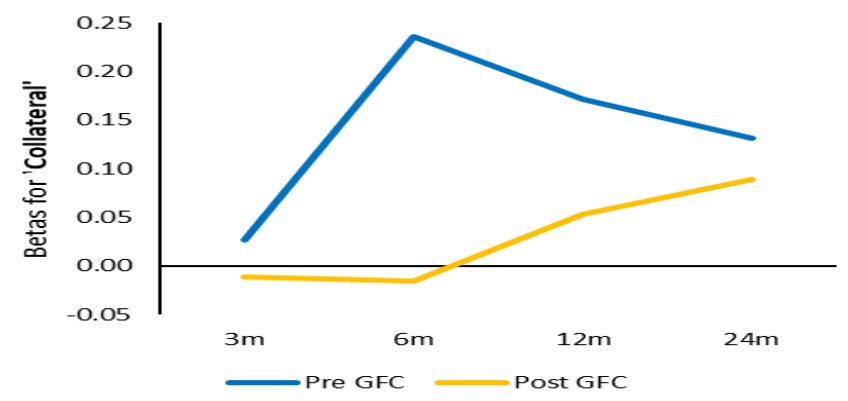

Source: IMF staff. 
Figure 2. Market Plumbing

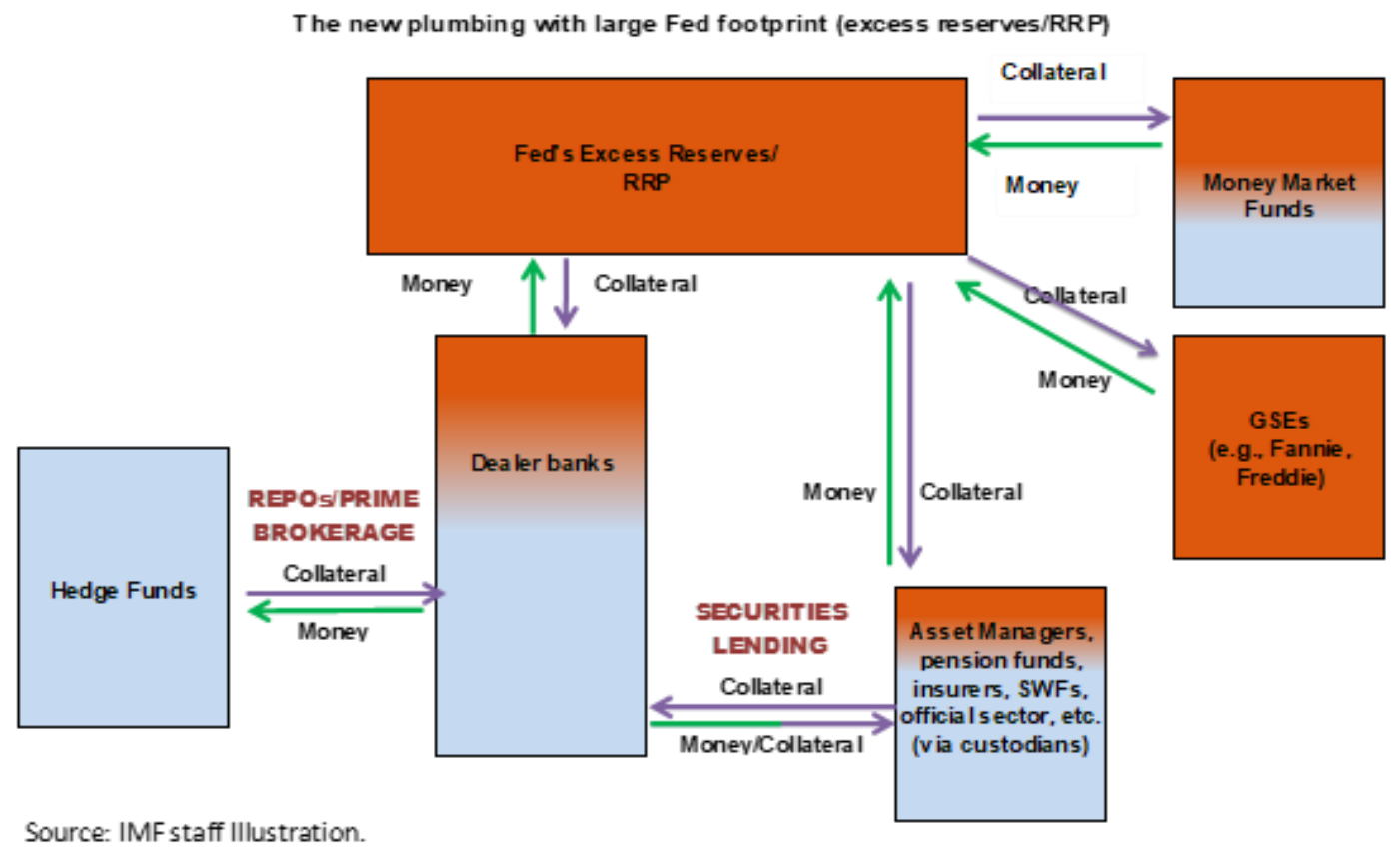

Notes: Blue area is market plumbing; rest is the public-sector balance sheet

Some argue that the operating framework for monetary policy is now different which leads to the need for large reserves post-normalization. However, ECB's Bindseil in his Jackson Hole speech (2016), suggested that lean balance sheets would reflect a healthy focus of central banks on their core mandate, i.e., monetary policy, and that large balance sheets should therefore be linked to exceptional periods in which the effective lower bound to short-term interest rates is binding (although post-crises balance sheet normalization obviously takes time):

"[An] outstandingly lean central bank balance sheet was the one of the Fed pre-crisis, where the total balance sheet length was only around 1.1 times the total amount of bank notes in circulation. In general, the objective of a lean balance sheet should remain valid in the future long-term Operating Framework, even if monetary and FX policies, or in some cases auxiliary central bank tasks, can justify some lengthening. ...the idea that the central bank permanently injects monetary accommodation through a longer balance sheet with substantial holdings of a portfolio of less liquid assets with long maturity and possibly some credit riskiness does not appear sufficiently convincing." (Bindseil, 2016)

In summary, transmission from long-tenor bonds to the short-end market rates is weaker (Box 2) in the period post-Lehman when central banks are normalizing. This is in sharp contrast to the period pre-Lehman when transmission from the pledged collateral market was significant especially for the 6-12 months duration (which is the "sweet spot" due to the moneyness argument discussed in Section II). This impairment largely stems from the reduced availability of good collateral (e.g., U.S. treasuries or German bunds) due to central banks QE program(s) in advanced economies. From a plumbing and monetary policy 
transmission perspective, central bank arguments for large balance sheets in steady-state warrant further research. ${ }^{8}$

\section{Dealer Balance Sheet Space and Financial Conditions}

Since empirical work on central bank balance sheet unwind in advanced economies is unprecedented, it is possible that there is no one-to-one relation between policy rate hikes and the unwinding of central bank balance sheets. Why?

First, because letting the balance sheet shrink would release "good" collateral such as U.S. treasury securities, while reducing the excess reserves that commercial banks keep on deposit at the Fed. These deposits came about when the Fed bought up trillions of dollars in securities in a bid to keep long-term interest rates low, a strategy known as quantitative easing. Many of the securities were bought from nonbank financial firms (pension funds, insurers, and asset managers) which stashed the proceeds at depository institutions. Those banks in turn deposited money at the Fed, where it earned interest (only banks can earn interest on excess reserves.) Nonbanks are likely to reuse good collateral, rather than sizeable deposits at banks that have remained idle.

Second, good collateral, when pledged, is constantly reused in a process that is similar to money creation that takes place when banks accept deposits and make loans. That is why good collateral and excess reserves are very different in their implications for market functioning. The relation between the two may not even be positive because, presently, U.S. treasuries in the hands of the market, with reuse, are likely to lubricate markets, while excess reserves (or money) have remained idle in recent years. ${ }^{9}$

There is a link between excess reserves and the two-way monetary transmission. Policy papers and associated research usually focus on the monetary policy transmission lens that is from short-end policy rates to long-end (10 years and beyond). In recent years, policy rate hikes have not percolated to the long end of the yield curve, as shown by the Fed since lift off in December 2015. Furthermore, Box 2 shows that the transmission form long-end to shortend is also weaker now in the post-Lehman era.

The balance-sheet space of the banking sector is inundated with deposits from the QE-era (money from depositors who sold bonds to the Fed during QE). These deposits at the Fed, also called excess reserves of the banking system, are presently around US\$1.8 trillion. The

\footnotetext{
${ }^{8}$ In other words, there need to be underlying economic arguments about why reserves should be preferred over money-like U.S. treasuries (see Ihrig et. al, 2017 referenced above).

${ }^{9}$ U.S. treasury securities and excess reserves are substitutes since both are HQLA. However, the former can be reused while the latter cannot. So, from a market plumbing angle, U.S. treasury securities are as good or better lubricant than excess reserves.
} 
limited balance sheet space has inhibited financial intermediation in recent years, and in turn, monetary policy transmission. ${ }^{10}{ }^{11}$

As central banks unwind their balance sheets in the future, they will need to be careful to let the market have possession of securities as collateral, bought via QE, since the reuse rate of these securities is outside their control. If central banks' mandate is about monetary policy (and the liftoff of short-term rates), then cushioning duration-related volatility at the long-end of the U.S. Treasury curve seems to be a detour. With a large balance sheet, the unwind will be over a significant period of time, and thus not a short-term conflict (as is assumed in the monetary policy literature). ${ }^{12}$ However, going forward, the choice of balance sheet - private or public - should be transparent and driven by market forces and not by ad hoc allocation by central banks. More importantly, monetary policy transmission is weakened if parts of the plumbing move to central bank balance sheet.

\section{Collateral Reuse Rebounds-IMPlications for Money Market Rates}

The use (and reuse) of pledged collateral before the Lehman crisis was at par with the velocity of monetary aggregates like M2. A plethora of research (Bank of England, De Nederlandsche Bank, and Reserve Bank of Australia), and regulatory work streams in public and private sectors ( $\underline{F S B}, \underline{D T C C}$, etc.) have investigated this issue since estimates of collateral reuse (or, velocity) were first calculated (Singh 2011). For the uninitiated, the ratio of the total pledged collateral received by the large banks, divided by the primary sources of collateral, is the velocity of collateral - intuitively, the ratio measures the reuse of collateral due to financial intermediation between banks and nonbanks (also coined as "collateral chains"). As background, research in this area has argued that collateral velocity has been lower in recent years, initially due to the Lehman-crisis and elevated counter-party risk in

\footnotetext{
${ }^{10}$ As an analogy, oil is only needed for lubricating a car's engine; similarly, excess reserves, are needed only to smoothen out the need for reserves in the financial system. They were close to zero before the Lehman crisis. Now instead of an "oil change" we are carrying the oil in the car trunk, in our homes, everywhere.

${ }^{11}$ Deposits with the banks doubled post Lehman. Typical growth rate of deposits in line with disposable household income (about 5 percent) per year since 1950s. However, the doubling of deposits is a huge change for the banking system to absorb in a span of 3-5 years. The asset side also has to grow in line with deposit growth and the new regulatory rules (for instance leverage ratio) leave "little space" for other non-deposit activity

12 Furthermore, if central banks remain part of the plumbing and take money directly from nonbanks, the financial plumbing that relies on such money gets rusted. As a result, the dealer banks that connect the money pools and collateral pools will unwind such connections. Without money, the dealer banks will in turn return the U.S. Treasury and agency MBS back to the securities-lenders in exchange for corporates/equities. The dealer banks will also give back securities to the hedge funds, as banks will not have funds from money market etc. So, the cost of funding long positions for non-dealers like hedge funds in the bilateral collateral market will go up, and demand for (and price of) securities will go down. Thus, the value of the pledged collateral (such as U.S. treasuries) falls - whether Fed sells them from their balance sheet or do reverse repo directly with nonbanks. Going forward, central banks' role in market plumbing due to large balance sheets that has kept collateral velocity muted will impact their monetary policy.
} 
GSIBs (i.e., the large global banks). In subsequent years, the reuse of collateral was constrained due to regulations that restrict dealer banks' balance sheet space (for example, via the leverage ratio), and due to central banks' purchases of good collateral (under various QE programs).

As of end-2017, the pledged collateral received by the major banks that could be onward repledged in their own name was around US\$7.5 trillion, an increase of 25 percent relative to end-2016 (see Figure 3); with almost all global banks active in peddling pledged collateral globally showing an increase in pledged collateral received. As compared to this, the pledged collateral market was stuck at approximately US\$6 trillion (Singh and Goel, 2018) for almost a decade since 2008 .

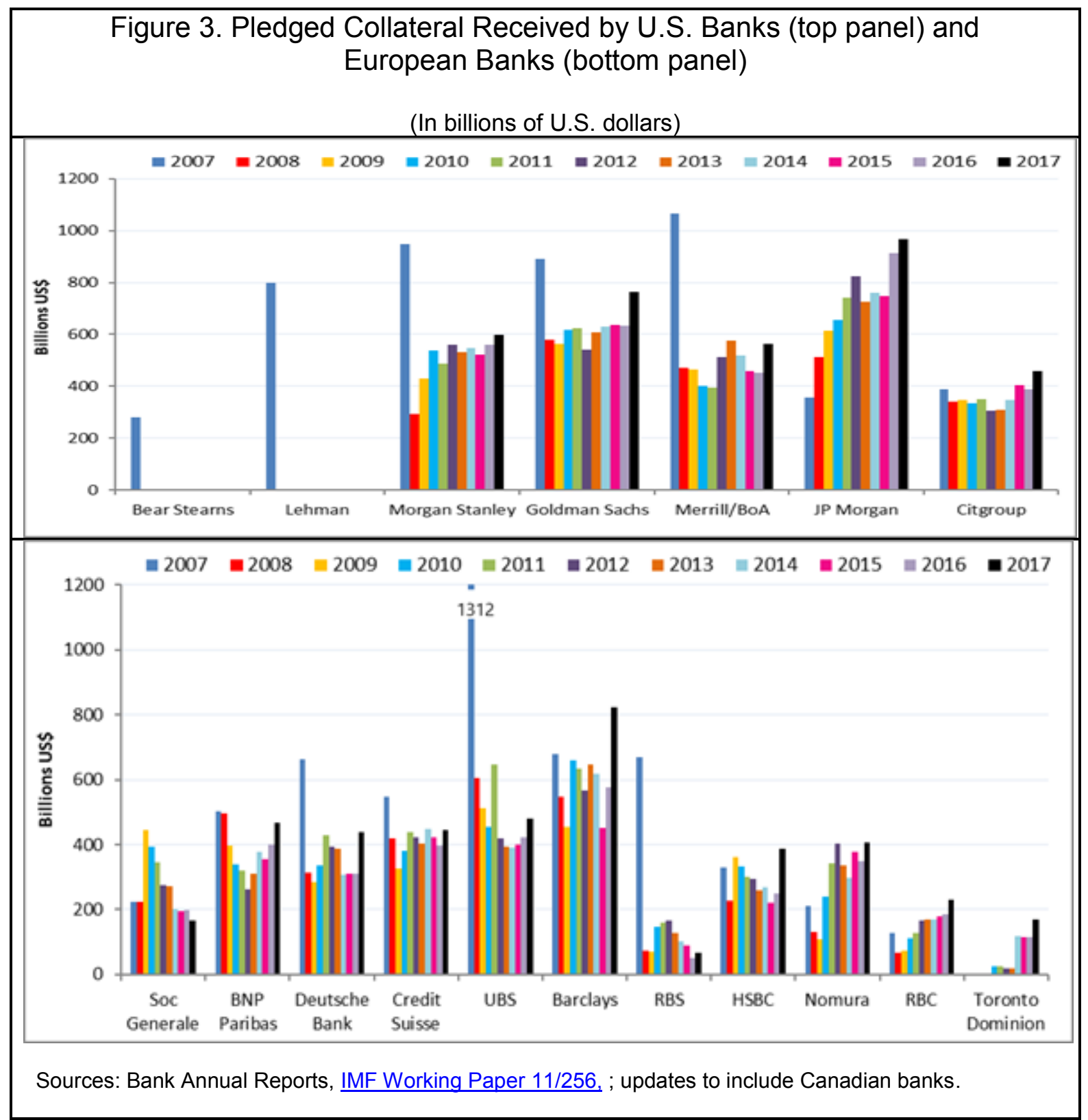


For global banks that are active in the pledged collateral market, there are two primary sources that pledge collateral to the banking system: hedge funds and other financial intermediaries. As shown in Table 1, in 2007 the velocity (or reuse rate) was US\$10 trillion/US\$3.3 trillion, or about 3.0. For end-2017, this ratio was US\$7.5 trillion/US\$3.7 trillion, or just above 2.0-a first time increase since the continuous decline since the Lehman crisis. ${ }^{13}$ This potential inflection point suggests that dealers are optimizing (and reshuffling) their balance sheet transactions in the aftermath of the new regulations to overcome balance sheet space constraints. Movements in short term rates will be more elastic (and higher), if collateral reuse and/or supply of collateral increases (Table 2). With a large U.S. Treasury pipeline for the issuance of short-tenor bills, plus the repatriation-related corporate selling of bonds, the supply of collateral is likely to increase relative to cash (and recent market rates show this trend).

\section{Table 2. Sources of Pledged Collateral, Volume of Market, and Velocity $(2007,2010-17)$}

(In trillions of U.S. dollars; velocity in units)

\begin{tabular}{|c|c|c|c|c|c|}
\hline \multirow[b]{2}{*}{ Year } & \multicolumn{3}{|c|}{ Sources } & \multirow[b]{2}{*}{$\begin{array}{l}\text { Volume of } \\
\text { Pledged } \\
\text { Collateral }\end{array}$} & \multirow[b]{2}{*}{$\begin{array}{l}\text { Reuse Rate } \\
\text { (or Velocity) }\end{array}$} \\
\hline & Hedge Funds & $\begin{array}{c}\text { Securities } \\
\text { Lending }\end{array}$ & Total & & \\
\hline 2007 & 1.7 & 1.7 & 3.4 & 10.0 & 3.0 \\
\hline 2010 & 1.3 & 1.1 & 2.4 & 6.0 & 2.5 \\
\hline 2011 & 1.4 & 1.05 & 2.5 & 6.3 & 2.5 \\
\hline 2012 & 1.8 & 1.0 & 2.8 & 6.1 & 2.2 \\
\hline 2013 & 1.85 & 1.0 & 2.85 & 6.0 & 2.1 \\
\hline 2014 & 1.9 & 1.1 & 3.0 & 6.1 & 2.0 \\
\hline 2015 & 2.0 & 1.1 & 3.1 & 5.8 & 1.9 \\
\hline 2016 & 2.1 & 1.2 & 3.3 & 6.1 & 1.8 \\
\hline 2017 & 2.2 & 1.5 & 3.7 & 7.5 & 2.0 \\
\hline
\end{tabular}

Sources: Risk Management Association; Singh (2011); updates to include Canadian banks.

\footnotetext{
${ }^{13}$ Non-hedge fund data suggests that pension, insurers, official sector and asset managers had US\$1.5 trillion in securities on loan as of end-2017 (without secondary market churning) — a sizable increase relative to 2016, thanks to sec-lending by national banks in the eurozone and some emerging markets (foreign exchange management and enhancing returns beyond coupons). The other source for pledged collateral are hedge funds with asset under management of US\$3.0 trillion (end-2017). In summary, total pledged collateral from nonhedge funds sources (US\$1.5 trillion) and from hedge funds (US\$2.2 trillion) amount to US\$3.7 trillion.
} 


\section{A. Conclusions}

Looking forward, what does central banks' balance sheet unwind, and forthcoming regulatory tweaks (e.g., leverage ratio) entail for short-term money market rates?. First, we show that the unwind of good collateral like U.S. treasuries or bunds from central bank balance sheets to the market is likely to improve transmission to the short-end money market rates. Second, as central banks contemplate a tightening cycle, an increase in collateral reuse eases financial conditions since dealer balance sheets space increases; thus, there is less rational for the plumbing to use the central bank balance sheet.

Central bank arguments for large balance sheets in steady-state warrant further research. For example, there need to be underlying economic arguments about why reserves should be preferred over money-like U.S. treasuries. Also, the need for large excess reserves for intraday payments, are not obvious when liquidity coverage and related regulations for a wholesale deposit "run" are more apt. Some recent attempts to show the impact of collateral reuse from long tenor bonds are in the right direction but data are limited to the eurozone, whereas the pledged collateral market is global. More frequent data reporting by all large global banks will be a welcome move to enhance our understanding of the transmission from long-term bonds to short-end market rates. Also, it will be useful to discern to what extent has the regulatory need for collateral adversely impacted the pledged collateral market. 


\section{Annex I. Model Specification to Box 2}

Policymakers and investors routinely decompose bond yields into expected rates and risk premiums to better understand the information embedded in the yield curve. The return on a government bond should conceivably correlate with variables that captures some component of either the quantity or the price of risk around the path of risk-free rates. Furthermore, given that the expected rate path was bolted near zero, during the QE time period, the macroeconomic relationship was impacted by the Fed. As analyzed by Christensen and Rudebusch, $\underline{2012}$, the impact on U.S. Treasury yields due to QE mainly reflected through lower policy rate expectations. To address this issue, one alternative is to just analyze the drivers of the risk premia (which is a broader lens than term premia and includes other factors such as collateral reuse, etc.).

To determine what affects risk premia researchers commonly estimate the econometric relationship between these estimates and observable macroeconomic and financial "factors." Relevant factors include forecasts of economic growth and inflation, as well as measures of uncertainty around those projections; budget deficit forecasts and supply factors related to "special demand" for safe assets (e.g., collateral reuse); estimates of the volatility of bond returns; and estimated covariance of bond and stock returns, to assess hedging value

Our econometric model is adapted from a similar model as used in GFSR April 2018, Box 1.2, to understand the role of collateral, and the long-end variables in driving the short-end of the curve. We use the risk premia variable (Actual yield minus OIS forwards) at 3,6,12, and 24 months, as our dependent variable in the regressions. Our independent variables are

1. Size of the Global Collateral Market

2. Determinants of Risk Premia

$$
\text { Risk Premia }=\alpha+\beta * \text { Global Collateral }+\sum \gamma * \text { Proxy }
$$

To avoid multi-correlation issues and model errors, we run a total of 216 regressions with all possible combinations by selecting one variable from each of the group $(3 \times 3 \times 2 \times 2 \times 3 \times$ 2 ). Then we shortlist only those regressions which are within the $90^{\text {th }}$ percent of the highest $\mathrm{R}^{\wedge} 2$. This enables us to use only those regressions which have a high explanatory power and eliminate the spurious ones. As also discussed in GFSR April 2018, Box 1.2, such models generally track the estimated term premiums for Canada, France, Germany, Japan, U.K., and U.S. reasonably well over a 22 year sample.

We first run the regressions over the entire time sample (from 2002-17) to understand the role of collateral in explaining the short to medium-term risk premia. The analysis indicates that collateral's predictive power is significant across the short as well as medium-term horizons. However, since multiple tests show a structural break in late 2007, we split out regressions in two parts, and run for 2002-07, and 2008-17 separately. The results indicate that role of collateral has reduced in the post-GFC era both in terms of the coefficient of transmission, as well as the significance of these coefficients. 
Annex I. Model Specification to Box 2 (continued)

\section{Determinants of Risk Premia}

1. Group 1: Inflation Dynamics (3 variables)

a. Expected Inflation, Oil Spot Price, percent odds on deflation

2. Group 2: Growth Dynamics (3 variables)

a. Expected GDP growth, Expected Unemployment, percent odds on $<0$ GDP growth decline

3. Group 3: Supply (2 variables)

a. Expected budget surplus/GDP, Foreign Custody Holdings

4. Group 4: Real Term Premia (2 variables)

a. Standard Deviation of GDP growth, S\&P GARCH Return Volatility

5. Group 5: Inflation and Nominal Risk Premia (3 variables)

a. Standard deviation of inflation, Standard deviation of Rate Survey, GARCH 1-year Return Volatility

6. Group 6: Correlation Dynamics (2 variables)

a. M-GARCH A-DCC, M-GARCH A-DC Beta 


\section{References}

Adrian, Tobias, Richard Crump, and Emanuel Moench, 2013, "Pricing the Term Structure with Linear Regressions," Journal of Financial Economics, Vol. 110.

Anderson, Ronald W, and Joeveer Karin, 2013, “The Economics of Collateral” DTCC.

Arrata, William, Benoit Nguyen, Imene Rahmouini-Rousseau, and Miklos Vari, 2018, "The Scarcity Effect of Quantitative Easing on Repo Rates: Evidence from the Euro Area," IMF Working Paper 18/258, (Washington: International Monetary Fund).

Baranova, Yuliya, Zijun Liu, and Joseph Noss, 2016, "The Role of Collateral in Supporting Liquidity,” Bank of England Working Paper No 609.

Bindseil, Ulrich, 2016, “Evaluating Monetary Policy Operational Frameworks,” Federal Reserve Bank of Kansas City Presentation on "Designing Resilient Monetary Policy Frameworks for the Future."

Brainard, Governor Lael, 2017, "Cross-Border Spillovers of Balance Sheet Normalization," Speech at the National Bureau of Economic Research's Monetary Economics Summer Institute, Cambridge, Massachusetts, July.

Cheung, Belinda, Mark Manning, and Angus Moore, 2014, “The Effective Supply of Collateral in Australia" Reserve Bank of Australia, Quarterly Bulletin (September).

Christensen, Jens H.E., and Glenn D Rudebusch, 2012, "The Response of Interest Rates to U.S. and U.K. Quantitative Easing," Federal Reserve Bank of New York, May.

Copeland, Adam, Linsey Molloy, and Anya Tarascina, 2018, What Can We Learn from the Timing of Interbank Payments? https://libertystreeteconomics.newyorkfed.org/2019/02/whatcan-we-learn-from-the-timing-of-interbank-payments.html

Del Negro, Marco, Domenico Giannone, Marc P Giannoni, Andrea Tambalotti, 2017, "Safety, Liquidity and the Nature Rate of Interest," Federal Reserve Bank of New York, May.

Domanski, Dietrich, Hyun Song Shin and Vladyslav Sushko, 2015, "The Hunt for Duration: Not Waving but Drowning," BIS Working Papers, No. 519.

Dudley, William C. 2017, "The Importance of Financial Conditions in the Conduct of Monetary Policy," Remarks at the University of South Florida Sarasota-Manatee, Sarasota, Florida, March.

Financial Stability Board, 2017, "Transforming Shadow Banking Into Resilient MarketBased Finance: Re-Hypothecation and Collateral Re-Use: Potential Financial Stability Issues, Market Evolution and Regulatory Approaches," January. 
Gelos, Gaston, Federico Grinberg, Shujaat Khan, Tommaso Mancini-Griffoli, Machiko Narita, and Umang Rawat, 2019, "Household Indebtedness did not Weaken U.S. Monetary Transmission Post-Crisis,” VOX CEPR Policy Portal, February.

Hordahl, Peter and Oreste Tristani, 2014, "Inflation Risk Premia in the Euro Area and the United States," International Journal of Central Banking, September.

Ihrig, Jane, Edward Kim, Ashish Kumbhat, Cindy M. Vojtech, and Gretchen C. Weinbach, 2017, "How Have Banks Been Managing the Composition of High-Quality Liquid Assets?," Finance and Economics Discussion Series 092.

International Monetary Fund (IMF), 2018, Global Financial Stability Report: A Bumpy Road Ahead. Washington, DC, April. Box 1.2.

Jank, Stephan and Emanual Moench, (Forthcoming 2019), "Safe Asset Shortage and Collateral Reuse."

Kaminska, Izabella, 2015, "What is Hyper Liquidity Made of?," Financial Times Alphaville, August.

_ 2019, "Don't Fear the Year-End Funding Squeeze," Financial Times Alphaville, January.

Koning JP, 2012, "Why Moneyness," Remarks made at the blogpost by JP Koning, December.

Malik, Sheheryar, and Andrew Meldrum, 2016, "Evaluation the Robustness of U.K. Term Structure Decompositions Using Linear Regression Methods," Journal of Banking and Finance, pp. 85-102.

Potter, Simon 2015, "Money Markets and Monetary Policy Normalization," Remarks at the Money Marketeers of New York University, New York City, April 15.

Quarles, Randal K., 2018, "Liquidity Regulation and the Size of the Fed's Balance Sheet," Remarks at the Hoover Institution Monetary Policy Conference, Stanford University, California, May 4.

Singh, Manmohan, 2011, "Velocity of Pledged Collateral: Analysis and Implications" IMF Working Paper 11/256, (Washington: International Monetary Fund).

__, 2016, “Collateral and Financial Plumbing” Risk Books, United Kingdom.

_ , 2017a, "Collateral Reuse and Balance Sheet Space,” IMF Working Paper 17/113, (Washington: International Monetary Fund).

— 2017b, "Why Shrinking the Fed Balance Sheet may have an Easing Effect," Guest post in the Financial Times, April 24. 
Singh, Manmohan, and Haobin Wang, 2017, "Central Bank Balance Sheet Policies and Spillovers to Emerging Markets," IMF Working Paper 17/172, (Washington: International Monetary Fund).

Singh, Manmohan, and Rohit Goel 2018a, "Bank Business Model Shift Softens Impact of Stimulus Withdrawal," Financial Times Alphaville, December.

Singh, Manmohan, and Phil Prince, 2018b, Moneyness and Term Premia, Financial Times Alphaville, Feb 15, https://ftalphaville.ft.com/2018/02/15/2198837/guest-post-moneyness-andterm-premia/.

Stella, Peter, 2015, What is Hyper Liquidity Made of? August, https://ftalphaville.ft.com/2015/08/06/2136580/what-is-hyper-liquidity-made-of/

Williamson, Stephen D., 2014, "Scarce Collateral, the Term Premium, and Quantitative Easing” Federal Reserve Bank of St Louis, March. 